\title{
Article 9 at a Crossroads: Interference Before and After Eweida
}

\section{Megan Pearson*}

\begin{abstract}
This article considers when an interference with Article 9 should be found. It argues that while some limits are necessary, it is sufficient that there is 'intimate connection' between a religiously motivated act and a belief, and there should be no requirement of religious obligation or impossibility. It demonstrates that the historic approach of the ECtHR has been to overly limit the circumstances in which an interference with rights can be claimed, particularly in employment. It argues that the approach developed in Eweida $v$ United Kingdom demonstrates a deeper understanding of the importance of Article 9, giving it broader effect, but that this is likely to mean that the Court will be faced with hard decisions as to when religious claims can be protected.
\end{abstract}

Keywords: freedom of religion - interference - Article 9 European Convention on Human Rights - Eweida v United Kingdom - employment rights

\section{Introduction}

Freedom of conscience and religion is probably unique in its potential to challenge almost every area of law. Since society contains a multitude of religious

*PhD Candidate in Law, London School of Economics (m.r.pearson@1se.ac.uk).

This is a pre-copyedited, author-produced PDF of an article accepted for publication in the Human Rights Law Review following peer review. The version of record [Human Rights Law Review (2013) 13 (3): 580-602] is available online at hrlr.oxfordjournals.org/content/13/3/580.full.pdf 
and moral beliefs, many religious people will constantly be faced with practices with which they disagree and will in a myriad of ways be constrained from living an ideally religious life. Not all of this can constitute an interference with the right under Article 9 to manifest belief 'in teaching, practice and observance'. However, the European Court of Human Rights' (ECtHR) approach has historically been unnecessarily restrictive in considering whether an interference under Article 9(1) exists, thus shutting out cases at an early stage of reasoning and before justification is considered under Article 9(2). This approach has been narrowed even further by the British courts.

Article 9 has therefore been of limited use to claimants. The first full case to be heard on it by the Court was not until $1993^{1}$ as earlier cases were ruled inadmissible by the Commission. However, the ECtHR's approach is currently in a state of flux, as demonstrated by Eweida $v$ United Kingdom ${ }^{2}$ and is moving to a broader approach that correctly moves the attention to the justification stage.

This article focuses on Article 9(1) and the question of interference. It does not consider when interferences will be justified. The first part will consider various proposals for deciding 'where rights begin'. ${ }^{3}$ It will then address specific questions arising from ECHR and English case law on the topic, considering in particular whether it should be possible to claim an interference where the conflict could be avoided by resigning from employment or taking other similar action. The third section will consider the change brought by Eweida and discuss some remaining issues that have not yet been resolved.

\section{Possible Tests}

What amounts to an infringement of Article 9 is perhaps only matched in difficulty by the question of what is an infringement of the right to respect for a private and family life under Article 8 . Part of the problem is that religion can be

\footnotetext{
${ }^{1}$ In Kokkinakis v Greece (1994) 17 EHRR 397.

${ }^{2}$ This is four conjoined cases: Eweida v United Kingdom Application No. 48420/10; Chaplin $v$ United Kingdom Application No. 59842/10; Ladele v United Kingdom Application No. 51671/10; McFarlane v United Kingdom Application No. 36516/10, Merits, 15 January 2013.

${ }^{3}$ Lupu, 'Where Rights Begin: The Problem of Burdens on the Free Exercise of Religion' (1989) 102 Harvard Law Review 933.
} 
central to a way of life and relevant to every decision a person makes. However, quite clearly, there have to be some constraints to keep the right within manageable limits.

\section{A. Impossible to comply with religious beliefs?}

The narrowest test is that in order to find an interference a religiously compelled act must be legally forbidden. ${ }^{4}$ This appears to be the approach taken in Cha'are Shalom Ve Tsedek $v$ France $^{5}$ which held there was no interference with religious rights where compliance with religious beliefs was not impossible. The applicant organisation was one of Ultra-Orthodox Jews who required meat certified as 'glatt' and not merely kosher. They were denied a licence to ritually slaughter animals on the grounds that there was a licensed slaughterer in the area, albeit one that only produced kosher meat. The ECtHR held there would be an interference 'only if the illegality of performing ritual slaughter made it impossible for ultra-orthodox Jews to eat meat from animals slaughtered in accordance with the religious prescriptions they considered applicable. ${ }^{6}$ Given that glatt meat could be imported from Belgium this standard was not met. Taken at face value, this sets an extremely high standard. An impossibility test would permit severe burdens on belief without requiring any justification at all for the policy to be given.

It could be objected that if the case is unsuccessful it does not really matter whether it is rejected at the interference or justification stage. However, the importance of finding an interference is that it means justification for the infringement has to be given. If a claim is rejected at the interference stage it makes no difference how ill thought out the policy, how unimportant the interest it protects, or how badly tailored the solution, because the right is formally considered not to be affected. Indeed, since there is no consideration of whether the action complies with a legitimate aim, such action could be taken out of mere dislike. ${ }^{7}$ It also excludes any

\footnotetext{
${ }^{4}$ The possible tests are partly drawn from Greenawalt's discussion of when a 'substantial burden' should be found under American law: Greenawalt, 'Religion and the Constitution Vol. 1' (Princeton: Princeton University Press, 2002).

${ }^{5}$ Application No. 27417/95, Admissibility, 27 June 2000.

${ }^{6}$ Ibid. at para 80.

${ }^{7}$ Although probably not for discriminatory reasons as this would raise separate issues under Article 14 ECHR.
} 
attempts to find less intrusive measures that protect the rights and interests on both sides.

Even in restrictions made for the best of motives, at minimum, the state should have the obligation to explain why a right has been burdened. Winners and losers are inevitably created in all litigation. However, the loser has a right for the winner's claim to be "justified on some ground found satisfactory to an outside arbiter" ${ }^{8}$ and for the outside arbiter to justify, and not merely enforce, their decision on the loser. This is part of the 'culture of justification', a vital part of the human rights project that the ECHR protects. The culture of justification is not only beneficial for society in ensuring that decisions made by the state are justifiable. The process also benefits the individuals involved, even if they ultimately still lose their case. Too strict a test of interference may result in greater anger following unfavourable decisions than would otherwise be felt. Stychin argues that:

'While proponents of freedom of religion may accept the need for balancing, they are more likely to advocate that it should be done openly as a majoritarian limitation on the exercise of the right, rather than constitutively in the definition of its scope. ${ }^{10}$

To be told that you have suffered an injury, and this is unfortunate, but, 'alas, cannot be accommodated in practice, given other important such demands ${ }^{11}$ is more likely to be acceptable to a claimant, than simply to be told that no recognisable harm has been suffered. Indeed Calhoun refers to this as 'losing twice': the claimant not only loses their case but loses the recognition that they had a valid claim to make. ${ }^{12}$

\footnotetext{
${ }^{8}$ Brown 'Liberty: The New Equality' (2002) 72 New York University Law Review 1491.

${ }^{9}$ Cohen Eliya and Porat, 'Proportionality and the Culture of Justification' (2011) 59 The American Journal of Comparative Law 463.

${ }^{10}$ Stychin, 'Faith in the Future: Sexuality, Religion and the Public Sphere' (2009) 29 Oxford Journal of Legal Studies 729 (emphasis in original).

${ }^{11}$ Taylor, 'Living with Difference' in Allen and Regan (eds) Debating Democracy's Discontent: Essays on American Politics, Law and Public Philosophy' (Oxford: Oxford University Press, 1998) at 218.

${ }^{12}$ Calhoun, Losing Twice: Harms of Indifference in the Supreme Court (New York: Oxford University Press, 2011).
} 
Happily, the high standard in Cha'are Shalom Ve Tsedek does not represent the court's usual thinking. It was an unusual case. As presented by the court, the claim was a purely practical matter over access to meat that met strict religious standards. Since Ultra-Orthodox Jews did not face significant difficulty in obtaining such meat, as an equally good alternative to slaughtering the animals themselves was open to them, there could be no interference. It is possible this would be acceptable reasoning in another case: if there is little problem in fulfilling a religious obligation, then it is difficult to see how a right has been interfered with.

Nevertheless, of course, this did not mean that the test to decide interference should be described so restrictively and indeed even on the unusual facts, the Court fails to fully analyse the issues in question. The major problem is that it sees religion only as a purely individual concern rather than as potentially communal or institutional. At the heart of the case was a dispute between the applicant organisation and the Association Consistoriale Israélite de Paris (ACIP), a much larger organisation that controlled the sale of kosher meat and had a licence from the government to slaughter animals. Cha'are Shalom Ve Tsedek had split from this organisation because it considered its interpretation of dietary and other laws insufficiently strict. The two organisations had attempted to reach an agreement permitting Cha'are Shalom Ve Tsedek to slaughter animals under ACIP's auspices, but this failed owing to financial disagreements. The real problem therefore was the French government's favouritism of ACIP and its permitting it to maintain its monopoly when challenged by other Jewish organisations. The ECtHR failed to truly recognise this, even though it did find that the French government's argument that it had to prevent the proliferation of slaughterhouses tenuous. Overall then, this was a highly unusual case which had little to do with individual religious belief, and cannot be taken as authority that compliance must not be impossible.

Problems with the test can be seen if it is applied to a more usual pattern of facts. In the Canadian case of Alberta v Hutterian Brethren of Wilson Colony, ${ }^{13}$ some Hutterites objected on religious grounds to photographs being taken of them because they considered that this violated the Second Commandment, prohibiting the creation of idols or 'any likeness of what is in heaven above or on the earth beneath or in the 
water under the earth'. ${ }^{14}$ The Canadian Supreme Court held that a new requirement ${ }^{15}$ that all driving licences had photographs and the picture placed in Alberta's facial recognition data bank, was an interference with the Hutterites' beliefs, although this was justified. But, even though not having a driving licence would make their rural farming existence very difficult, this would not be sufficient under the impossibility test. The Hutterites could hire drivers, even though this would conflict with their religious beliefs in self-sufficiency. Thus they would have been forced either to break a religious principle or to change an important aspect of their way of life, without raising any rights issue at all. Of course, this is not to say that the Hutterites should necessarily have won: concerns about identification may be sufficient reason to enforce the policy, but it would be wrong to have cut off the case before the government was called on to prove this.

\section{B. Religious obligation or religious motivation?}

Even if an impossibility test is rejected, this leaves open the question of whether the issue must concern a mandatory religious rule. Suggestions that a religious obligation is required can be seen in a number of early Commission cases such as $X v U K{ }^{16}$ This however was a weak case where the complaint was that a Buddhist prisoner was prohibited from publishing articles in a Buddhist magazine: a rather tenuous and remote interference. More problematic is $X v$ Austria $^{17}$ which held that there was no interference with the rights of members of the Unification Church who were prohibited from setting up a legal association for the Church, since this was not essential in order for them to practice their religion.

A religious obligation test should not be required. Defining what is religiously motivated rather than religiously required is difficult. ${ }^{18}$ An obligation requirement creates an impulse to 'dutify' every aspect of religion. This may be quite artificial. Laycock puts this as follows:

\footnotetext{
${ }^{14}$ Exodus 20:4.

${ }^{15}$ Previously there had been an exception for those with religious objections.

${ }^{16}$ Application No.5442/72, Admissibility, 20 December 1974.

${ }^{17}$ Application No. 8652/79, Admissibility, 15 December 1981.

${ }^{18}$ Laycock, 'The Remnants of Free Exercise' (1990) Supreme Court Review 1.
} 
It assumes that the exercise of religion consists only of obeying the rules... all the affirmative communal and spiritual aspects of religion are assumed away... for many believers the attempt to distinguish what is required from what grows organically out of the religious experience is an utterly alien question, perhaps nonsensical. ${ }^{19}$

Take for example a woman who wishes to become a nun in the Catholic Church. To her it may seem that she has a religious calling and to be prevented from doing so by the state would be to violate a religious duty. However, it could not be said that there is a general obligation within Catholicism to become a nun, although interference with this decision affects the deepest aspects of a person's religious identity. Similarly, some Muslim women would say it is an absolute religious obligation to wear a headscarf. Others would see it more as a matter for personal reflection and choice. It is also unclear why two women who saw the practice in different ways, even though they had both reached the same decision for religious reasons, should be treated starkly differently.

It is probable that some religious practices are put in terms of duty because this is more likely to be accepted by a court. ${ }^{20}$ However, requiring a religious compulsion may simply involve the court in difficult religious questions. Proving whether or not an act is a religious obligation is likely to be difficult, particularly in non-hierarchical religions. Not all religions have definite rules or doctrines. ${ }^{21}$ However, they may still have practices which are clearly part of the religion, even where there is no textual or other authority to which an adherent can point. Religious beliefs are often personal and there is likely to be a broad range of beliefs within religions. A religious obligation test is likely to require expert testimony, and thus potentially turn the enquiry into a test of religious orthodoxy.

Even if there were a clear distinction between compulsion and motivation, religious duties may be less important to a believer than religiously motivated conduct. For example, most Christian denominations do not think it is a religious requirement

\footnotetext{
${ }^{19}$ Ibid. at 24.

${ }^{20}$ Sullivan, The Impossibility of Religious Freedom (Princeton: Princeton University Press, 2005).

${ }^{21}$ See e.g. O'Brien, 'Chant Down Babylon: Freedom of Religion and the Rastafarian Challenge to Majoritarianism' (2002) 18 Journal of Law and Religion 219.
} 
to attend Bible study groups, but for some it may be an important part of their religious practice. It would be a nonsense to say that a law that made studying a sacred text with others a criminal offence did not interfere with freedom of religion. A state that sought to make such behaviour illegal could probably only be acting for illegitimate reasons or at least disproportionately. Excluding mundane, but legitimate, reasons such as regulations about noise or traffic, which would apply to any meeting, any government that forbade such groups would be likely to be acting either to prevent opposition to itself or from a policy of religious intolerance. Any test that permitted such state behaviour without inquiry simply does not protect a fundamental human right sufficiently. To conclude then, it should be sufficient for an act to be religiously motivated, although the fact that it is not mandatory may be relevant when considering justification.

\section{All religiously motivated practices?}

The ECtHR has consistently held that 'Article 9 does not protect every act motivated or inspired by a religion or belief ${ }^{\prime 22}$ and has drawn a distinction between practices merely motivated by belief and those which are a 'manifestation' of belief, where there is an intimate connection between the act and the belief. Although the term manifestation is perhaps unclear, the idea that some practices motivated by religious belief are too remote to be protected is irreproachable. Cases such as Rushton $v$ Nebraska Public Power District ${ }^{23}$ should not give rise to a claim. Two employees of a nuclear power station refused drug testing, not because they were religiously opposed to it, but because the company's drug policy statement stated that alcoholism was a disease that could be treated. Contrary to this, they believed that alcoholism was not a disease but a sin. They therefore did not wish to affirm the policy.

Including such a case would place weighty burdens on employers and the state in assessing these claims. It may encourage frivolous or spurious claims, made not for reasons of protecting conscience but to make political points or simply to cause disruption. Although the importance of the practice would be assessed at the

\footnotetext{
${ }^{22}$ Arrowsmith v UK (1981) 3 EHRR 218 at 228.

${ }^{23} 653$ F.Supp. 1510 (D.Neb.1987).
} 
balancing stage, and therefore cases involving indirect unimportant interferences would be unlikely to be ultimately successful, there is still benefit in excluding some cases via a threshold test. The employees were not asked to directly do something which was against their beliefs (either a religious obligation or a motivated by a religious precept). The link was much weaker. Even the symbolic element is remote: whether or not the employer considered alcoholism a sin had little to do with the safety reasons for requiring drug testing at a nuclear power station, and there was no reason why adhering to this policy would have led anyone to question their views on alcoholism.

In $C v U K^{24}$ the Commission held that there was no interference where a Quaker refused to pay tax to support military activities because of her pacifist beliefs, wanting to pay into a 'peace fund' which would not be used for military activities. That the law is of general application is not sufficient justification for excluding tax cases, since that is also likely to be the case for most laws which impose direct and severe burdens on religious beliefs. It is also not sufficient to argue that providing such a fund would lead to administrative chaos as it would inevitably lead to more demands. While this is an important consideration, it should be dealt with under justification not interference. The real justification is that the burden is too remote: $\mathrm{C}$ was asked to take no action which demonstrated her approval of or required any involvement in military activities: she simply had a general obligation to pay taxes, which would be used for a variety of purposes.

Nevertheless, a fairly broad approach to the question of protected acts should be taken, which takes seriously the full range of religious practice. This has not always been the case. Buxton LJ in R(Williamson) $v$ Secretary of State for Education and Employment, ${ }^{25}$ held Article 9 was restricted to 'worship, proselytism and possibly... to mandated religious "practice", and then only to practices which were a 'clear, uniform and agreed requirement of the religion in question', ${ }^{26}$ although his argument on this point was not accepted by the rest of the Court of Appeal and overruled by the House of Lords ${ }^{27}$ He therefore considered that a claim from parents

\footnotetext{
${ }^{24}$ Application No. 10358/83, Admissibility, 15 December 1983.

${ }^{25}$ [2003] Q.B. 1300 (Court of Appeal).

${ }^{26}$ Ibid. at 1314.

${ }^{27}$ [2005] 2 A.C. 246
} 
to permit teachers to perform corporal punishment in private Christian schools because of a religious belief that it was necessary in order to ensure children's moral behaviour, based on Biblical edicts, had no protection under Article 9.

Pichon and Sajous $v$ France, ${ }^{28}$ a case about the refusal of pharmacists to provide contraception which will be discussed further below, also gives a very narrow definition of the kinds of activity protected holding that:

The main sphere protected by Article 9 is that of personal convictions and religious beliefs, in other words what are sometimes referred to as matters of individual conscience. It also protects acts that are closely linked to these matters such as acts of worship or devotion forming part of the practice of a religion or a belief in a generally accepted form.

Such a narrow protection of religious practice is not sufficient. It is a very cramped understanding of what religion is to many believers: 'a total account of life, organizing, explaining and justifying all action... generat[ing] elaborate systems of belief, institution and ritual applicable to all areas of life' ${ }^{29}$ It suggests that religion is all very well in its place, but it should not be taken too seriously.

Buxton LJ's further argument that the practice must be 'clear and uniform' is also highly problematic. Within any religion there is likely to be disagreement, perhaps extensive, on religious issues and stricter or more lenient interpretation of religious doctrine. Far from being a problem, this pluralism in religious belief should, broadly speaking, be protected. There is no reason why a guarantee of religious freedom should be a protector of religious orthodoxy. Such an approach also requires an intensive and potentially intrusive analysis into religious belief and sets the court up as a theological authority. Many religious doctrines are not immediately perceptible from religious texts. For example, it is not immediately obvious that the Biblical injunction to 'abstain from blood ${ }^{30}$ means that Jehovah's Witnesses are forbidden from receiving blood transfusions, but this is nevertheless a sincere

\footnotetext{
${ }^{28}$ Application No. 49853/99, Admissibility, 2 October 2001.

${ }^{29}$ Cochran Religion in Public and Private Life (London: Routledge, 1990) at 65.

${ }^{30}$ Acts 15:20.
} 
religious conviction which, assuming competence to make medical decisions, should be respected by courts.

It is for good reason that the majority of the Court of Appeal and the House of Lords rejected Buxton LJ's approach. It may seem surprising that corporal punishment is a protected action, but the parents' belief that it was part of a religiously required way of raising children was sincere and important. The important issues about the protection of children can be dealt with under the question of justification.

Some cases though are more complex and require a difficult line to be drawn. In Skugar v Russia ${ }^{31}$ a woman refused to accept a taxpayer identification number because she believed it contained a number which 'was a forerunner of the mark of the Antichrist'. ${ }^{32}$ The court held that, 'general legislation which applies on a neutral basis without any link whatsoever with an applicant's personal beliefs cannot in principle be regarded as an interference. ${ }^{33}$ The court made reference to US law, and in particular to Employment Division $v$ Smith. ${ }^{34}$ This though is in tension with the usual protection of Article 9. Employment Division $v$ Smith held that there was no interference with the free exercise right under the First Amendment where there was a prohibition on the use of peyote, including for Native American religious ceremonies. Smith only permits a very small number of cases, essentially those where there appears to be a discriminatory intent, to give rise to any claim. However, this is not the ECtHR's position. The court has held that forced compliance with generally applicable laws where this is contrary to religious beliefs can be a violation of Article 9. ${ }^{35}$ Indeed it has held that failing to treat a person differently because of their religious beliefs can be a violation of Article $14 .^{36}$

While Skugar's reasoning is therefore unpersuasive, the decision is justifiable. Skugar did not have to use the taxpayer number, which was automatically created for her, as she could identify herself to the tax authorities using personal information such

\footnotetext{
${ }^{31}$ Application No. 40010/04, Admissibility, 3 December 2009.

32 Ibid.

${ }^{33}$ Ibid.

${ }^{34} 494$ U.S. 872 (1990).

${ }^{35}$ e.g. Bayatyan v Armenia (2012) 54 EHRR 15.

${ }^{36}$ Thlimmenos v Greece (2001) 31 EHRR 15.
} 
as her name and date of birth. She was trying to challenge an internal matter of the tax authorities. Its affect on her was therefore too remote.

The weakest form of interference with beliefs are what Lupu calls 'atmospheric burdens' or the 'behavioral trends and patterns in society at large'. ${ }^{37}$ These should not be considered enough to give rise to a claim. Living in a society that does not generally share your religious beliefs may make living according to religious precepts more difficult, but this does not mean that the failure to change society to conform to your beliefs constitutes an interference with your rights. Merely being aware that people have different views on a matter does not interfere with a right even if this causes offence.

Whilst there are a number of cases which declare that 'atmospheric burdens' are relevant to the limitation of rights under Article 10, this does not mean that religious offence gives rise to a free standing right under Article 9. It is true that in Otto-Preminger Institut $v$ Austria ${ }^{38}$ for example an art-house cinema was prevented from showing a film which was undoubtedly potentially offensive to Christians ${ }^{39}$ on the basis that it violated 'the respect for the religious feelings of believers as guaranteed in Article 9 ${ }^{40}$ However, although these cases confusingly say that the action is justified on the basis of the rights of others, it is clear from Choudhury $v$ $U K^{41}$ that there is no such freestanding right. A Muslim man argued that the High Court's refusal to grant him permission to bring a private prosecution against Salman Rushdie for blasphemy in his book The Satanic Verses, failed to protect his rights under Article 9. He failed on the basis that there was no right to 'bring any specific form of proceedings against those who... offend the sensitivities of an individual or group' ${ }^{42}$ This would clearly be a great violation of the right of free expression as well as the religious freedom of the writer, who would be coerced into outwardly respecting religious views which he did not respect. In reality, Otto-Preminger-

\footnotetext{
${ }^{37}$ Lupu, supra $\mathrm{n} 3$

${ }^{38}$ (1995) 19 EHRR 34. See also IA v Turkey (2007) 45 EHRR 30; Handyside v UK (A/24) (1979-80), 1 EHRR 737

${ }^{39}$ The film was about a nineteenth century play which 'portrays God the Father as old, infirm and ineffective, Jesus Christ as a "mummy's boy" of low intelligence and the Virgin Mary, who is obviously in charge, as an unprincipled wanton' Ibid. at para 21.

${ }^{40}$ Ibid. at para 56.

${ }^{41}$ Application No. 17439/90, Admissibility, 5 March 1991.

${ }^{42}$ Ibid.
} 
Institut seems to have more to do with the doctrine of the margin of appreciation than any real acceptance of such a broad positive right.

Overall, despite some overly restrictive decisions particularly in Commission decisions, the Court appears to have reached a sensible general conclusion that there is an interference if an act is a manifestation of a sincere religious conviction, provided that there is an intimate connection between the act and the belief. This provides a workable test which excludes remote burdens but which is broad enough to respond to the reality of religious belief and practice.

\section{The 'specific situation' rule}

This fairly positive picture was however greatly marred by the ECtHR's use of 'the specific situation rule'. This holds that if there is a conflict between a religious obligation and another obligation, normally an employment obligation, which can be avoided by resignation or similar action, then there is no interference with the right. In Pichon and Sajous $v$ France $^{43}$ therefore the Court held that requiring pharmacists to sell contraceptive pills did not interfere with their right to freedom of religion because they could avoid this conflict by leaving their employment. Thus their application was dismissed as manifestly ill founded. Similarly, in Ahmad $v U K^{44}$ there was held to be no interference where a teacher wished to arrange his timetable so that he could attend mosque on Friday lunchtimes, as it was held he could have avoided this conflict by resigning or taking up a part-time contract. ${ }^{45}$

This principle has been almost universally criticised and for good reason. The first problem is in the assumption that employment is truly voluntary. Given that for most people employment is an economic necessity, that finding alternative employment of any kind, and particularly on the same terms, may be difficult, and that there is no guarantee that all workplaces will not prohibit such conduct, choice may be very constricted. Furthermore, given that people's values and religious beliefs

\footnotetext{
${ }^{43}$ Supra n 28.

${ }^{44}$ (1982) 4 EHRR 126.

${ }^{45}$ Other cases include Konttinen $v$ Finland Application No. 24949/94, Admissibility, 3 December 1996; Karaduman v Turkey Application No.16278/90, Admissibility, 3 May 1993; Kalaçv Turkey (1997) 27 EHRR 552.
} 
change over time, the dilemma is not necessarily something which has been actively been chosen, but rather simply arisen.

More fundamentally, it is also questionable whether it really matters that the dilemma is in some way caused voluntarily. This emphasis on choice is strangely confined only to this issue. In some ways the point of human rights is to protect people from harsh consequences arising from their unpopular choices. Furthermore, the problem of voluntariness even in employment is not in other contexts taken to be an absolute bar. If resignation were always sufficient to protect rights then this would make employment a 'rights-free zone', which is not true either as a matter of practice or principle. In Copland $v U K^{46}$ for example it was held there was a violation of an employee's Article 8 rights where her internet usage, phone calls and emails were monitored at work when there was no law in force which regulated such monitoring. The fact that she could resign and avoid such intrusion was not discussed.

There are also problems of discrimination. If rules, for example, against religious clothing are applied to all employment, it may have a discriminatory effect 'since it could result in the disappearance of entire communities from visible membership of the government workforce without raising any Article 9 issues at all. ${ }^{47}$ Since it is likely that the religion of the majority is likely to be accommodated simply because they have political power or because such arrangements are seen as natural and therefore not questioned, it is minorities who are likely to be disproportionately affected. This is seen very clearly in French law, which prohibits only 'obtrusive' religious symbols in state schools ${ }^{48}$ thus prohibiting the Muslim headscarf and the Sikh turban, but not the wearing of small crosses. Similarly Christian teachers are very likely to receive Sundays and religious holidays such as Easter and Christmas off work without question because this is simply the way the school timetable is run. This is not to say that there is anything necessarily wrong with this: when some will always be disadvantaged it makes sense to disadvantage the

46 (2007) EHRR 37

${ }^{47}$ Edge 'Religious Rights and Choice under the European Convention on Human Rights' [2000] 3 Web Journal of Current Legal Issues, available at: http://webjcli.ncl.ac.uk/2000/issue3/edge3.html (last accessed 24 April 2013)

${ }^{48}$ Loi n $^{\circ}$ 2004-228 du 15 mars 2004 encadrant, en application du principe de laïcité, le port de signes ou de tenues manifestant une appartenance religieuse dans les écoles, collèges et lycées publics 
fewest, and change on such matters which are embedded in cultural consciousness is likely to be highly contentious. However, it demonstrates that there is nothing necessarily neutral in such standards.

More broadly, the specific situation rule is unprincipled. It denies the right of justification discussed above and ignores the fact that freedom of religion is a basic right. That a person can resign is relevant to the balancing test and may be ultimately be the choice they are put to, but the specific situation approach prevents even the consideration of rights. As Gunn puts it, it means that the "'fundamental rights" of the European Convention are subject to a simply contractual waiver' ${ }^{49}$ If freedom of religion is a "one of the foundations of a "democratic society"... one of the most vital elements that go to make up the identity of believers and their conception of life... and a precious asset" ${ }^{, 50}$ then surely it should be protected in employment, which is after all where a large part of everyday life is spent. ${ }^{51}$ These claims may involve only minor parts of an employee's duties or minor variation to uniform standards but still lead to resignation.

If this were the only way to achieve results which were intuitively sensible, then it could perhaps be supported. However, this is not the case. The court's reasoning in Pichon and Sajous was essentially a balancing process: women were entitled to access contraception with ease, the applicants were acting in the public sphere and they could manifest their beliefs in other ways. Similarly in Ahmed, it may have been justified for the school to refuse permission: it may have been too difficult administratively to change his timetable so that he was not teaching on Friday lunchtimes. However, all these issues can be discussed in reference to whether infringement of the practice was justified, and not to the prior question of whether the right was infringed.

\section{A. Reconsideration of the Specific Situation Rule?}

\footnotetext{
${ }^{49}$ Gunn, 'Adjudicating Rights of Conscience under the European Convention on Human Rights', in Van der Vyver and Witte (eds), 'Religious Human Rights in Global Perspective: Legal Perspectives' (The Hague: Martinus Nijhoff, 1996).

${ }^{50}$ Kokkinakis supra $\mathrm{n} 1$

${ }^{51}$ Although the fact that it is a workplace may be relevant to how these rights can be exercised.
} 
The ECtHR appears to have recognised some of this criticism. The specific situation rule was first implicitly reconsidered in Dahlab $v$ Switzerland, ${ }^{52}$ a case decided shortly before Pichon and Sajous, but by a different Section of the Court. Dahlab was a teacher in a state infant school who was told she could not wear the hijab while teaching (although she had in fact worn it without problems for a considerable period). Although the case was declared inadmissible on the, perhaps rather specious grounds, that a 'powerful religious symbol' such as a hijab would have a proselytising effect on young children and the restriction was therefore proportionate to the aim of protecting the rights and freedoms of others, public order and public safety, there was no argument that her right was not infringed.

The reconsideration edged further towards being explicit in Sahin v Turkey. ${ }^{53}$ Sahin was a university student who was prohibited from attending university while wearing a headscarf. As she felt this was her religious duty, and since she was prohibited by law from wearing her headscarf at any university in Turkey, her only chance to pursue her hope of a medical degree and comply with her religious belief was to study abroad, which she eventually did. However, the Grand Chamber avoided addressing the question directly, but adopted the Chamber reasoning that the 'Court proceeds on the assumption that the regulations in issue...constituted an interference with the applicant's right to manifest her religion. ${ }^{54}$ This was therefore a rather lukewarm reconsideration. However, given the highly politically controversial nature of Sahin it might be thought that the Grand Chamber would have taken this opportunity to dispose of the case, without ruling on controversial issues about state secularism and the dangers of political Islam, if they had agreed with the specific situation approach.

There was subsequently greater, if still implicit reconsideration of the idea at the Strasbourg level in cases involving Article 8 rather than 9, as highlighted by Leigh. ${ }^{55}$ Schüth and Obst $v$ Germany ${ }^{56}$ involved claims by employees who had been dismissed by religious organisations because of extra-marital relationships and

\footnotetext{
${ }_{52}^{52}$ Application No. 42393/98, Merits, 15 January 2001.

${ }^{53}$ (2007) 44 EHRR 105

${ }^{54}$ Ibid. at 120.

${ }^{55}$ Leigh, 'Balancing Religious Autonomy and Other Human Rights under the European Convention' (2012) 1 Oxford Journal of Law and Religion 109.

${ }^{56}$ (2011) 52 EHRR 32.
} 
claimed this was a violation of Article 8. Their claims were not dismissed at the interference stage but instead proceeded to the balancing stage, where Schüth's claim was successful. These cases though involve Article 8 and while there appears to be little reason in principle why Article 8 should have greater protection than Article 9, the specific situation approach could still have been maintained. However, in a case heard a few months later, Siebenhaar $v$ Germany, ${ }^{57}$ there was found to be an interference with Article 9 where a nursery assistant was dismissed from her employment with the Lutheran Church when it was discovered she was a member of the Universal Church, although on the facts no violation was found. A new approach was therefore signalled before Eweida $v U K$ was heard.

\section{B. The specific situation rule in domestic law}

While the slow process of reconsideration began, such developments were not taking place at domestic level. Rather the specific situation rule was firmly entrenched. This is obvious from $R$ (Begum) v Headteacher and Governors of Denbigh High School. ${ }^{58}$ Begum wanted to wear a jilbab to school, described as a 'long coat-like garment', 59 but her school only permitted her to wear a shalwar kameeze, which she considered not modest enough to comply with her religious obligations. The majority of the House of Lords held that there was no interference with her right because she chose to attend the school and there were other schools in the area which would permit her to wear it. The reasoning is unsatisfactory. Firstly, Begum was not in an analogous situation with employment because she was legally required to attend school and it was originally her parent's choice and not hers which secondary school she attended. As it happens, the school appears to have put a great deal of effort into ensuring that the uniform complied with the religious precepts of most of its students and to have refused further changes to the uniform on the basis that it would lead to peer pressure to comply with stricter standards of dress. However, this is strictly irrelevant. As the argument is that the existence of other schools and her choice in attending a school with a uniform code is sufficient, the school was under no obligation to even consider

\footnotetext{
${ }^{57}$ Application No 18136/02 (3 February 2011). It is referred to by Leigh supra $\mathrm{n} 55$.

${ }^{58}$ [2006] UKHL 15, [2007] 1 AC 100.

${ }^{59}$ Ibid. at 109.
} 
her demands, or to provide any alternative to the standard school uniform at all. The upheaval that would be caused by moving schools is immediately discounted. Of course, this may well have been the best result but compromise can only be decided in the context of justification. It also created a very different approach in domestic law between religious discrimination and race discrimination, meaning that religious groups who could also be considered racial groups received greater protection. ${ }^{60}$

This very limited approach to religious freedom was evident in the four cases which led to the application to Strasbourg in Eweida $v$ UK. In Ladele v Islington $L B C{ }^{61}$ a registrar refused to perform civil partnerships because she believed that they were 'contrary to God's instructions'. ${ }^{62}$ In McFarlane $v$ Relate (Avon) Ltd, ${ }^{63}$ a counsellor for Relate refused to provide psycho-sexual counselling to gay couples because he felt this would require him to condone their sexual behaviour. In Chaplin v Royal Devon and Exeter Hospital NHS Foundation Trust $t^{64}$ a nurse was told she could not wear a cross on a chain around her neck, although she was permitted to clip it onto her badge or lanyard. In Eweida $v$ British Airways Plc ${ }^{65}$ a member of BA's check-in staff also wanted to wear a cross visibly. In the first three cases they were all dismissed. ${ }^{66}$ In Eweida's case, after she refused alternative employment within the company in a non-customer facing role, BA, after considerable public outcry, changed the rules to permit employees to wear a cross and she returned to work.

In all four cases, it was held that there was no interference with their rights under Article 9. In Ladele, the Court of Appeal quoted Pichon and Sajous ${ }^{67}$ approvingly. The question of violation was addressed together with interference and Sahin was used, not to signal a broader approach in considering interference, but in demonstrating the limited nature of Article 9 generally. The approach had been even more limited in the Employment Appeal Tribunal which had held that the protection

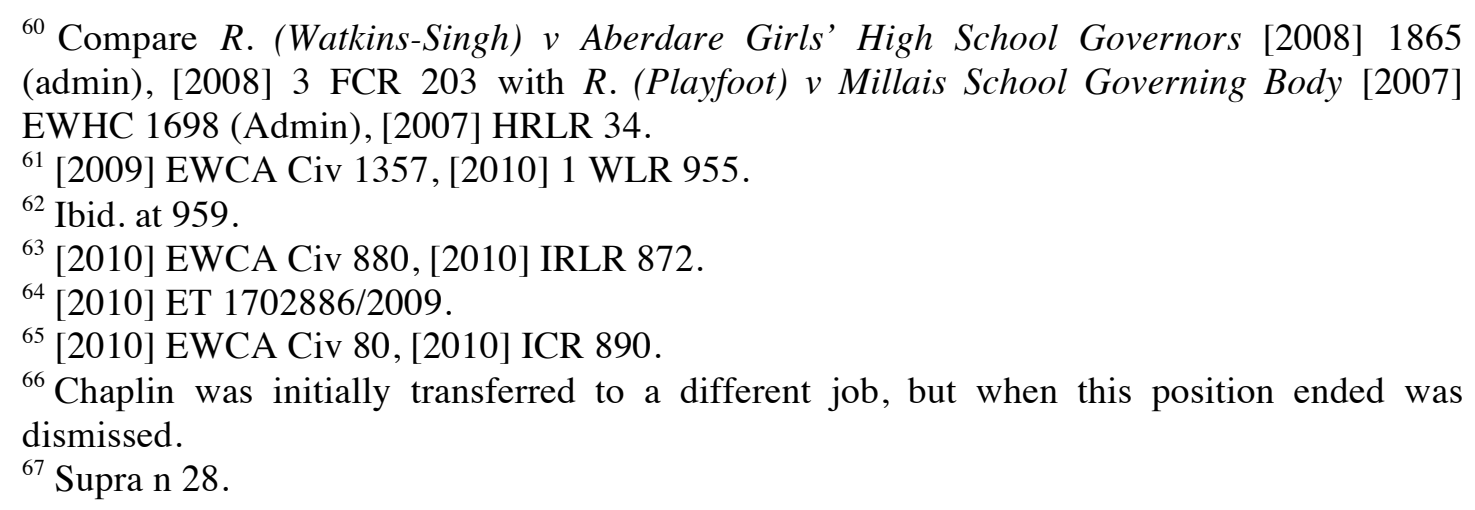


for Article 9 rights was 'very narrow protection indeed. ${ }^{68}$ McFarlane followed similar reasoning. In Eweida it was held that 'the jurisprudence on Article. 9 does nothing to advance the claimant's case ${ }^{99}$ and quoted Begum in finding that:

The Strasbourg institutions have not been at all ready to find an interference with the right to manifest religious belief in practice or observance where a person has voluntarily accepted an employment or role which does not accommodate that practice or observance and there are other means open to the person to practise or observe his or her religion without undue hardship or inconvenience. ${ }^{70}$

Article 9 has therefore not been of much practical use as far as the British courts were concerned, at least in employment or similar cases. This had been the subject of judicial criticism, most notably in Copsey $v$ WWB Devon Clays $L t d,{ }^{71}$ but given that it had been approved by the House of Lords in Begum and that it showed no signs of wanting to reconsider it (the Supreme Court having denied permission to appeal in Ladele and Eweida) this undeniably represented the law.

This is not to say though that the specific situation rule excluded all claims. In $R$ (National Secular Society) v Bideford Town Council ${ }^{72}$ a councillor claimed it violated his Article 9 rights when the council said prayers at the beginning of council meetings. The court declined to hold that because he had stood for election knowing that prayers were said, he should be taken to have accepted this. ${ }^{73}$ The reasoning is clearly right. An elected office is not the same as other employment, because as the court held, there is a fundamental right of voters to choose who they wish to represent them. Alternative "employment' ${ }^{74}$ probably does not exist and is in any case irrelevant. In the earlier case of Williamson, ${ }^{75}$ discussed above, it was held that the

${ }^{68}$ [2009] ICR 387 at 413.

${ }^{69}$ Supra $\mathrm{n} 65$ at 888 .

${ }^{70}$ Ibid. at $888-9$.

${ }^{71}$ [2005] EWCA Civ 932 [2005] ICR 1789.

${ }^{72}$ [2012] EWHC 175 (Admin); [2012] 2 All E.R. 1175.

${ }^{73}$ Although in the circumstances the degree of awkwardness he felt by not joining in the prayers was held not sufficient to be an interference.

${ }^{74}$ Councillors are not paid but receive expenses.

${ }^{75}$ Supra n 27 
alternative must be practical and not merely theoretical. The Court of Appeal had held that the parents could have either educated their children at home, or could have attended school or waited until their children were home from school to discipline them. The House of Lords rejected these arguments as impractical. Nevertheless, the success of the argument up to this point demonstrates the narrowness of the Article 9 right in English law.

\section{The consequences of Eweida $v$ UK}

The combination of the beginning of reassessment of the specific situation rule and the restrictive approach of the UK courts laid the ground for a reconsideration of Article 9(1) in Eweida $v$ UK. In all four cases it was held there had been an interference with the applicant's rights under Article 9, or in Ladele (since there was no claim under Article 9 alone, but only Article 9 and 14) that the acts were within the ambit of Article 9. In fairly short reasoning, the ECHR made clear two important points. The first was that, while there must be a 'sufficiently close and direct nexus between the act and the underlying belief, ${ }^{76}$ there was no need for the practice to be religiously mandated. Protection was not limited to an 'act of worship or devotion which forms part of the practice of a religion or belief in a generally recognised form ${ }^{, 77}$ and thus a prohibition on wearing a cross could potentially be an interference. Secondly, the court disclaimed the specific situation rule, holding that it would be better to weigh the possibility of leaving employment at the balancing stage. Even McFarlane, who only objected to providing sexual, and not relationship, counselling to same sex couples, was not considered to have waived his rights by voluntarily enrolling on Relate's psycho-sexual counselling programme. Eweida $v U K$ therefore is an important decision. It gives the right in principle to manifest religious beliefs in employment and puts the focus on the question of justification, thus meaning that Article 9 claims should be taken seriously. However, as would be expected, questions still remain about the scope of Article 9(1) and it is to these that the article now turns.

\footnotetext{
${ }^{76}$ Supra n 2 at para 82 .

${ }^{77}$ Ibid.
} 


\section{A. Remaining Questions}

The first question relates to the residual role of choice and consent. Eweida $v U K$ clearly and correctly states that a person cannot be taken to have given up their rights merely because they have accepted particular employment. However, there must be some cases where claims can be ruled out without pushing organisations 'into the defensive stances of having to show justification for interference ${ }^{78}$ because a person has unequivocally accepted the interference. Denying the idea of choice has any relevance is also infantilising to the person claiming the right. For these reasons, in some truly voluntary situations there can be no interference with freedom of religion. For example, if a person joins a university Christian union, they cannot then complain that the society does not respect their atheist views as it holds prayers before each meeting. The free choice to join and leave the society adequately protects freedom of religion.

Even in some employment situations, there may be no interference in some circumstances. If a person willingly accepts a job when they are aware its intrinsic nature will be in conflict with their religious beliefs, it is difficult to see why they should be relieved of the consequences of their choice when the conflict is both obvious and avoidable. If for example the job is to perform abortions in an abortion clinic, a doctor cannot accept it and subsequently claim that performing abortions is an interference with her Catholic beliefs. This should be a very limited exception though and should apply in very few situations. It would not apply where a gynaecologist, although initially employed to perform abortions at a hospital, had a religious conversion and no longer wished to perform them, but would perform other medical procedures that the hospital performed, because the role of gynaecologist is not intrinsically in conflict with religious obligations. Again, it should be stressed that this does not necessarily mean such accommodation should be given: it will depend on the rights and interests of others.

This exception is potentially not only relevant to practical considerations, but also to an explicit and intrinsic workplace ethos. However, even greater care should

\footnotetext{
${ }^{78}$ Leader 'Futures and Freedoms: Personal Priorities, Institutional Demands and Freedom of Religion' (2007) 70 Modern Law Review 713, 722.
} 
be taken in holding that there is no interference in these situations. It should not be held that because, for example, McFarlane knew that Relate had as one of its aims a commitment to non-discrimination, there was no interference with his rights where he sought to discriminate. Similarly, Islington's 'Dignity for All' policy, which Islington held precluded Ladele's claim, was a commendable attempt to avoid discrimination and increase inclusion, but that does not mean it could require all employees to accept the 'thick' version of tolerance that lay underneath it. The particular views of its employees were not relevant to its activities or to the purpose of the organisation. However, there could be an argument that a Green Party councillor who voted against a motion in favour of same-sex marriage and was then expelled from the party, because this went against party policy, was not subject to any interference with her belief. ${ }^{79}$ Her role was intrinsically bound up with her beliefs. The right to express beliefs and remain within a political party can only be a limited one, as otherwise the distinctiveness and usefulness of political parties would be undermined.

So far the discussion has only focused on secular workplaces, but the question also arises as to whether there are individual rights to freedom of religion within religious organisations. It is clear from Schüth and Obst $^{80}$ and Siebenhaar ${ }^{81}$ that Article 8 rights exist within religious employment and also that, where a person is of a different religion, they can claim Article 9 rights if they are dismissed for this reason. It is also fairly clear that there can be an interference with the Article 9 or 10 rights of some employees if they are dismissed because they criticise particular doctrines of a religion. ${ }^{82}$ However, can Article 9 be used for greater internal challenges to religious doctrine? For example, a woman might claim that she believes it is her religious vocation to become a priest in the Catholic Church, and that, properly understood, Catholicism requires female priests and that the bar on women priests prevents her

\footnotetext{
${ }^{79}$ BBC News 'Brighton Green councillor's gay-vote expulsion upheld' 19 November 2012 http://www.bbc.co.uk/news/uk-england-sussex-20397281 (last accessed 24 April 2013).

${ }^{80}$ Supra $\mathrm{n} 56$.

${ }^{81}$ Supra $n 57$.

${ }^{82}$ Rommelfanger v Germany Application No. 12242/86, Admissibility, 6 September 1989. C.f. Fernandez-Martínez v Spain Application No. 56030/07, Merits, 15 May 2012, awaiting Grand Chamber Judgment.
} 
from living out her beliefs ${ }^{83}$ Evidently, there is sufficient justification for holding that this is not a violation, in terms of the collective religious freedom of the church and the religious freedom of those who are opposed to any change in policy, but is there an interference? Of course, in order to be caught by the ECHR there would have to be some state action, but this could be found in the fact that the state has not outlawed sex discrimination for certain religious posts, in contrast to most employment. So far the ECHR has rejected these types of arguments. Thus in Karlsson $v$ Sweden $^{84}$ where a priest was refused a post in the state church because of doubts over his ability to work properly with female priests the Court held there was no interference. He had to accept the policy of his church.

Such an approach is not inconsistent with the broader approach taken to interference in secular employment. Religious freedom is inherently limited when a person becomes a religious minister. A person has a right to try and change the practices and doctrines of a religion ${ }^{85}$ but there can be no right to ensure that that they are in conformity. A church must be able to choose its own doctrines.

\section{B. Substantive Limits?}

The discussion of Eweida and Article 9(1) has so far has been about in what circumstances religious beliefs are protected, rather than on limits on protected beliefs per se. Eweida also raises, although does not conclude, a second issue. This is about the substantive limits on the views that have protection under Article 9 and in particular what protection discriminatory beliefs receive. In the domestic courts in Ladele v Islington $L B C,{ }^{86}$ the Employment Appeal Tribunal held that if Ladele were given an exemption for refusing to perform civil partnerships this may breach Article 17 of the ECHR. The National Secular Society also made this point in its submission as intervener to the ECtHR.

\footnotetext{
${ }^{83}$ See Rutherford, 'Equality as the Primary Constitutional Value: The Case for Applying Employment Discrimination Laws to Religion' (1996) 81 Cornell Law Review 1049. I leave aside any Article 14 issues for present purposes.

${ }^{84}$ Application No. 12356/86, Admissibility, 8 September 1988.

${ }^{85}$ Although this is of course subject to limits that are 'necessary in a democratic society'.

${ }^{86}$ Supra $\mathrm{n} 68$. The Court of Appeal did not address this issue.
} 
Article 17 prevents 'any State, group or person' using the rights in the Convention to aim to destroy Convention rights and freedoms or 'their limitation to a greater extent than is provided for in this Convention'. The importance of preventing democracy being destroyed from within was readily ascertainable in the post-Second World War era and the idea still has significant importance, even if the line is difficult to draw in practice. On this basis it has been held that Article 10 does not to apply to Nazi doctrines ${ }^{87}$ since Nazism seeks to destroy the basis of democracy, or to violent speech ${ }^{88}$ because such violence is antithetical to the nature of democracy and a call for violence is to deliberately call to violate the rights of others.

However, not all discriminatory views fall outside the ambit of Convention protection. In Redfearn $v U K,{ }^{89}$ a bus driver, responsible mainly for driving disabled or elderly people, was dismissed because he stood for election as a British National Party (BNP) councillor. At the relevant time, the BNP's constitution held that the party stood, 'for the preservation of the national and ethnic character of the British people and is wholly opposed to any form of racial integration between British and non-European peoples. It is therefore committed to stemming and reversing the tide of non-white immigration' ${ }^{90}$ The ECtHR held that the fact he had no real opportunity to challenge this dismissal because of his political beliefs was a violation of Article 11. The Court denied that its role was 'to pass judgment on the policies or aims, obnoxious or otherwise, of the BNP at the relevant time ${ }^{, 91}$ and held that his right of freedom of association was protected by the Convention.

Article 17 is an inappropriate concept for the situation that arose in Ladele. It should be used only in very limited circumstances where the right sought is contrary to the nature of democracy or seeks to entirely deny the dignity of others. Ladele's views were undoubtedly offensive to many, including some of her colleagues. However, holding that her claim was beyond the pale of acceptable action and entirely unprotected would be unwarranted. Ladele did not seek to deny anyone the right to enter into a civil partnership, she merely refused to take part in their

\footnotetext{
${ }^{87}$ E.g. Kühnen v Germany Application No. 12194/86, Admissibility, 12 May 1988.

${ }^{88}$ E.g. Pavel Ivanov v Russia Application No. 35222/04, Admissibility, 20 February 2007.

${ }^{89}$ [2013] IRLR 51, Application No. 47335/06, Merits, 6 November 2012.

${ }^{90}$ Milmo and Rawlinson, '10 Things You Should Know About the BNP When You Watch Question Time Tonight' Independent, 22 October 2009.

${ }^{91}$ Supra $n 88$ at para 47.
} 
formation. The letter she wrote asking for an exemption was described as 'thoughtful and temperate'. ${ }^{92}$ Furthermore, as Elias $\mathbf{J}$ stated, 'fundamental changes in social attitudes, particularly with respect to sexual orientation, are happening very fast and for some - and not only those with religious objections - they are genuinely perplexing. ${ }^{93}$ While this is in itself perhaps not a principled reason for differential treatment, it demonstrates that some caution should be exercised. Indeed the ECtHR itself is slightly ambivalent on the issue. While discrimination on the grounds of sexual orientation requires "very weighty reasons', ${ }^{94}$ it is not a violation of the Convention for the state to discriminate in not providing same-sex marriage ${ }^{95}$ or presumably (although this has not been tested) any kind of legal relationship recognition for same-sex couples.

Although Ladele's actions were discriminatory, and potentially offensive, they cannot really be equated with the threat of undermining democracy at issue in Refah Partisi v Turkey ${ }^{96}$ or the Holocaust denial in Garaudy $v$ France.$^{97}$ Of course, the rights of others, both those who sought civil partnerships at Islington, and the wider public interest in non-discrimination, is relevant to the discussion, but this can be dealt with in the analysis of justification. The Court did not address the question of Article 17 in its judgment. However, it must have implicitly rejected such an argument since it found that there was an interference with Ladele's rights, although this was justified.

Further substantive restrictions have also been applied in some domestic cases which go beyond the requirements in Article 17. They were set out in Campbell and Cosans $v$ United Kingdom ${ }^{98}$ and require that the beliefs:

a) Attain a certain level of cogency, seriousness, cohesion and importance

b) Are worthy of respect in a 'democratic society' and are not incompatible with human dignity

c) Relate to a weighty and substantial aspect of human life and behaviour ${ }^{99}$

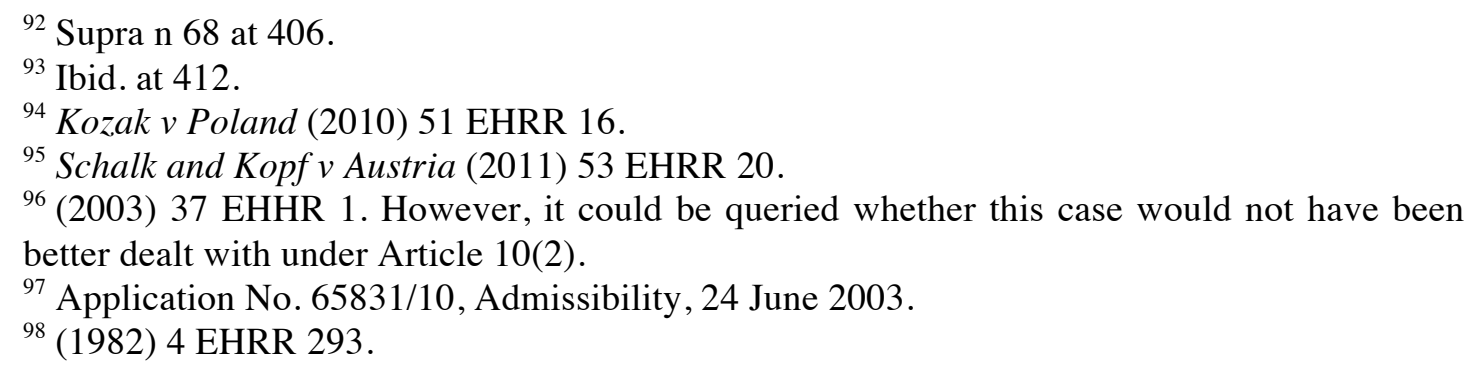


These criteria though originated in a claim involving the right of parents to ensure their children's education was in conformity with their religious and philosophical convictions under Protocol 1 Article 2, rather than an Article 9 case. Although these criteria certainly apply in English law, ${ }^{100}$ it is unclear whether the ECtHR also considers that they apply in this context. McColgan argues that they never applied to Article 9 claims and they were misapplied by the British courts. ${ }^{101}$ Certainly there is no mention of it in Eweida $v$ UK.

It is questionable whether there is need for the Cosans criteria to apply to religious beliefs under Article 9 beyond some minimal level of 'cogency, seriousness, cohesion and importance', ${ }^{102}$ as was stated in Eweida $v$ UK. Even coherence is a slippery concept. Given that many religious beliefs are hardly easy to understand and may rest on faith and allegory, it may be very difficult for those who are not members of a faith to understand it or to see how a religious text leads to the religious claim at issue. Care should therefore be taken that this does not become a test of religious orthodoxy or the restrictive view of religious practices argued for by Buxton LJ.

The criterion of 'worthy of respect in a democratic society' and not incompatible with human dignity' is more problematic. It is not that some substantive requirement is inappropriate: a religion which required the torture of children should not receive protection, but that placing a constitutive restriction on Article 9 is potentially open to abuse. Excluding the manifestation of beliefs because of the nature of the belief should only be a rare occurrence. As was said in Williamson, "in matters of human rights the court should not show liberal tolerance only to tolerant liberals'. ${ }^{103}$ There should be no restriction greater than that is applied under Article 17 to all rights. Otherwise this puts Article 9 at greater scrutiny than other rights, and invites illegitimate judgment of religious beliefs. New or unfamiliar religious beliefs can appear threatening even though, with hindsight, the threat they pose to social

\footnotetext{
${ }^{99}$ Williamson supra $\mathrm{n} 27$ at 273.

${ }^{100}$ Williamson Ibid.

${ }^{101}$ McColgan 'Religious Difference and Discrimination', From Theory to Practice: Religion \& Discrimination in a Changing World Conference, University College London, 8 November 2012, but see McCrudden 'Religion, Human Rights, Equality and the Public Sphere' (2011) 13 Ecclesiastical Law Journal 26.

${ }^{102}$ Supra $\mathrm{n} 2$ at para 81.

${ }^{103}$ Supra $\mathrm{n} 2$ at 268.
} 
order is minimal. ${ }^{104}$ Regrettably, state-approved discrimination against some religious minorities is still a great problem in some Member States, with action often being taken on the basis that their actions will undermine established religious traditions. ${ }^{105}$ Particular vigilance should therefore be taken in making sure that Article 9 is not overly restricted.

The arguments made in this section have not been fully worked out but rather aim to demonstrate that the welcome rejection of the specific situation rule opens up more difficult questions about the extent and role of Article 9. These issues will need to be addressed by the Court in the future.

\section{Conclusion}

As has been demonstrated, the question of when an interference should be found is a complex one. Like so many other issues, this area raises the difficult question of how different interests can be protected: here the balance between the interest in broad protection for religious beliefs and practices, with the interest in making sure decision-making does not become impossible because of the requirement to take into account numerous and opposing religious beliefs. Eweida $v U K$ deals with some these complexities and is a welcome extension and clarification of the extent of Article 9. Its most important aspect is its rejection of the specific situation rule. It seems to give a broad understanding of religious rights and to accept their importance both in and outside employment. It is a welcome step forward in the 'growing-up' process of Article 9 which appears now to have real relevance. The hypothetical plea Lewis imagines a potential claimant making of, 'Why do you tell us we have these freedoms when you are so obviously not prepared to protect them?' may no longer be so

${ }^{104}$ See Nussbaum The New Religious Intolerance: Overcoming the Politics of Fear in an Anxious Age (Cambridge MA: Harvard University Press, 2012); Harmer-Dionne, Once a Peculiar People: Cognitive Dissonance and the Suppression of Mormon Polygamy As a Case Study Negating the Belief-Action Distinction (1998) 50 Stanford Law Review 1295.

${ }^{105}$ Pollis 'Christians Against Christians' (2005) Journal of Human Rights 419; Flere, Dordević and Kirbiš, 'Six Cases Making a Pattern: Special Problems Arising in Countries with an Orthodox Tradition', Journal of Church and State, forthcoming, available from http://jcs.oxfordjournals.org/content/early/2013/02/26/jcs.cst002.full; Moscow Branch of the Salvation Army v Russia (2007) 44 EHRR 46. 
penetrating, ${ }^{106}$ What is certain though is that there is more important litigation to follow. As Mummery LJ stated in Copsey $v$ WWB Devon Clays Ltd:

It is probably only a matter of time, however, before the fundamental and pervasive character of Article 9 will be more fully revealed. If the Article means what it says, it has the potential to be far reaching in its legal, social, economic and political effects. ${ }^{107}$

${ }^{106}$ Lewis 'What not to wear: religious rights, the European Court, and the margin of appreciation' (2007) International \& Comparative Law Quarterly 395, 414

${ }^{107}$ Supra $\mathrm{n} 71$ at 1140 